\title{
Effect of metabolic acidosis on renal tubular sodium handling in rats as determined by lithium clearance
}

L.F. Menegon ${ }^{1}$, J.F. Figueiredo ${ }^{2}$ and J.A.R. Gontijo ${ }^{1}$

\author{
${ }^{1}$ Disciplina de Medicina Interna, Laboratório de Balanço Hidro-Salino, and \\ 2Disciplina de N efrologia, Laboratório de Conservação de Órgãos, \\ Núcleo de Medicina e Cirurgia Experimental, Departamento de Clinica Médica, \\ Faculdade de Ciências M édicas, Universidade Estadual de Campinas, Campinas, \\ SP, Brasil
}

\section{Correspondence \\ J.A.R. Gontijo \\ Departamento de Clínica M édica Faculdade de Ciências M edicas \\ Universidade Estadual de Campinas 13083-100 Campinas, SP \\ Brasil \\ E-mail: gontijo@venus.nmce- \\ fcm.unicamp.br}

Research partially supported by CNPq (No. 500868/91-3) and FAPESP (No. 91/0439-1).

Received May 8, 1997

Accepted June 3, 1998

\section{Abstract}

Systemic metabolic acidosis is known to cause a decrease in salt and water reabsorption by the kidney. We have used renal lithium clearance to investigate the effect of chronic, $\mathrm{NH}_{4} \mathrm{Cl}$-induced metabolic acidosis on the renal handling of $\mathrm{Na}^{+}$in male Wistar-Hannover rats (200-250 g). Chronic acidosis (pH 7.16 \pm 0.13$)$ caused a sustained increase in renal fractional $\mathrm{Na}^{+}$excretion $(267.9 \pm 36.4 \%)$, accompanied by an increase in fractional proximal $(113.3 \pm 3.6 \%)$ and postproximal $(179.7 \pm 20.2 \%) \mathrm{Na}^{+}$and urinary $\mathrm{K}^{+}(163.4 \pm 5.6 \%)$ excretion when compared to control and pair-fed rats. These differences occurred in spite of an unchanged creatinine clearance and $\mathrm{Na}^{+}$filtered load. A lower final body weight was observed in the acidotic (232 \pm $4.6 \mathrm{~g})$ and pair-fed $(225 \pm 3.6 \mathrm{~g})$ rats compared to the controls ( $258 \pm$ $3.7 \mathrm{~g}$ ). In contrast, there was a significant increase in the kidney weights of acidotic rats $(1.73 \pm 0.05 \mathrm{~g})$ compared to the other experimental groups (control, $1.46 \pm 0.05 \mathrm{~g}$; pair-fed, $1.4 \pm 0.05 \mathrm{~g}$ ). We suggest that altered renal $\mathrm{Na}^{+}$and $\mathrm{K}^{+}$handling in acidotic rats may result from a reciprocal relationship between the level of metabolism in renal tubules and ion transport.
There is a surprising lack of experimental data on the mechanisms of metabolic acidosis-induced disturbances in sodium handling by renal tubules. A few studies have indicated that systemic metabolic acidosis can decrease the reabsorption of salt and water by the kidney $(1,2)$. In particular, ammonium chloride-induced chronic metabolic acidosis has been shown to decrease water-salt reabsorption in dog kidney $(3,4)$. Using a free water clearance (C) technique (5) as an index of proximal tubular function, the effect of

\section{Key words}

- Renal function

- Renal sodium excretion

- Lithium clearance

- Metabolic acidosis ammonium chloride acidosis on renal ion balance appeared to be localized in the proximal tubule segments of the dog kidney. Sustained metabolic acidosis in man and other animals results in a progressive increase in the capacity to excrete ammonia in the urine $(1,4,6)$. This process may continue until practically the entire load of acid is excreted as ammonium salt. Nephron hypertrophy, which is characterized by an increase in cell protein content and cell size, is predominantly accounted for by an elevated renal tubule mass 
(7). This hypertrophy occurs in several disorders, such as diabetic nephropathy, the remnant kidney, and renal insufficiency. Chronic metabolic acidosis caused by feeding $\mathrm{NH}_{4} \mathrm{Cl}$ may also lead to nephron hypertrophy in the rat (7). Renal lithium clearance $\left(\mathrm{CLi}^{+}\right)$has been used as a noninvasive method to estimate the output of sodium and fluid by the proximal renal tubules and allows the study of various factors which influence sodium handling in different tubule segments $(8,9)$. The present study used lithium clearance to investigate the effects of chronic, $\mathrm{NH}_{4} \mathrm{Cl}$-induced metabolic acidosis on the renal handling of sodium.

The experiments were performed in male Wistar-Hannover rats (200-250 g) allowed free access to water and normal rat chow. The general guidelines established by the Declaration of Helsinki (1964) for laboratory animals were followed throughout the study. Metabolic acidosis was produced by substituting $0.25 \mathrm{M} \mathrm{NH}_{4} \mathrm{Cl}$ for the drinking water. All animals drank ad libitum and the volumes ingested were recorded. Only those rats which drank nearly equivalent amounts of water or $\mathrm{NH}_{4} \mathrm{Cl}$ were used. $\mathrm{NH}_{4} \mathrm{Cl}$-treated rats were maintained on their respective regimens for 10 days. To correct for the hypophagia induced by $\mathrm{NH}_{4} \mathrm{Cl}$ metabolic acidosis, renal function was also examined in animals (pair-fed) maintained on a level of food intake similar to that observed in the acidotic rats. Fourteen hours before the renal function evaluation, $60 \mu \mathrm{mol} \mathrm{LiCl} / 100 \mathrm{~g}$ body weight was given by gavage. The rats were subsequently housed individually in metabolic cages with free access to tap water but no food.

The experiments were performed in parallel for each group of control, pair-fed and acidotic rats. At 8:00 a.m., each animal received a tap water load by gavage (5\% of body weight), followed by a second load of the same volume $1 \mathrm{~h}$ later. Twenty minutes after the second load, the collection of spontaneously voided urine was initiated and con- tinued over a 2-h period. The voided urine passed through a funnel at the bottom of the cage into a graduated centrifuge tube. At the end of the experiment, blood samples were drawn by cardiac puncture and the kidneys were immediately removed, decapsulated and weighed. Plasma and urine sodium, potassium and lithium concentrations were measured by flame photometry, and creatinine concentration was determined spectrophotometrically by the alkaline picrate method (10). The results are reported as the mean \pm SEM per $100 \mathrm{~g}$ body weight.

Renal clearance was calculated by a standard formula $(\mathrm{C}=\mathrm{UV} / \mathrm{P})$ using the plasma creatinine and lithium levels for each period. Creatinine clearance was used to estimate the glomerular filtration rate (GFR) and $\mathrm{CLi}^{+}$ was used to assess proximal tubule output. Fractional sodium $\left(\mathrm{FENa}^{+}\right)$and potassium $\left(\mathrm{FEK}^{+}\right)$excretions were calculated as $\mathrm{CNa}^{+} /$ $\mathrm{CCr}$ and $\mathrm{CK}^{+} / \mathrm{CCr}$, respectively, where $\mathrm{CNa}^{+}$ and $\mathrm{CK}^{+}$are ion clearances and $\mathrm{CCr}$ is creatinine clearance. The fractional proximal $\left(\mathrm{PFENa}^{+}\right)$and post-proximal $\left(\mathrm{PPFENa}^{+}\right)$sodium excretions were calculated as $\mathrm{CLi}^{+} /$ $\mathrm{CCr} \times 100$ and $\mathrm{CNa}^{+} / \mathrm{CLi}^{+} \times 100$, respectively. Changes in fractional excretion were estimated using the control and pair-fed values. Statistical analysis of the data was performed using one-way analysis of variance for repeated measures. When the results were significant, Bonferroni's contrast test was used to determine the extent of the differences. $\mathrm{P}<0.05$ was considered to indicate significance.

Metabolic acidosis was confirmed by a blood $\mathrm{pH}$ of $7.16 \pm 0.13$. All rats survived the acidosis and were clinically healthy up to the tenth day of the study. As shown in Table 1 , a lower weight gain was observed in the $\mathrm{NH}_{4} \mathrm{Cl}$ and pair-fed rats after ten days. There was a significant increase in kidney weight but not in oral liquid intake in acidotic animals compared to the other experimental groups. Similarly, the serum potassium levels were significantly higher in the acidotic 
compared to the pair-fed and control rats (Table 1). The renal function results for the three groups of rats ten days after the induction of metabolic acidosis by $\mathrm{NH}_{4} \mathrm{Cl}$ are shown in Figure 1. Metabolic acidosis caused a sustained increase in renal fractional sodium excretion and potassium excretion which was accompanied by a rise in the fractional proximal and post-proximal sodium and urinary potassium excretions compared to the control and pair-fed rats (Figure 1). These differences occurred despite an unchanged creatinine clearance and sodium filtered load.

These findings are in agreement with previous studies $(2,3,5)$ that demonstrated a decreased sodium transport in the presence of a reduced $\mathrm{pH}$. Absolute and fractional sodium excretion was increased in acidotic animals although the filtered sodium load was similar to that of pair-fed rats. Sartorius et al. (11) reported the occurrence of natriuresis in the early phases of $\mathrm{NH}_{4} \mathrm{Cl}$-induced acidosis in humans. In rats and dogs undergoing metabolic acidosis there is a decrease in the renal tubular reabsorption of salt and water (2-4). Micropuncture studies have localized the site of this depressed sodium reabsorption to the proximal tubule $(5,6)$. A reduction in the proximal tubular reabsorption of salt and fluid in rats has been correlated with a reduced bicarbonate concentration in the peritubular capillaries (12). This observation may explain our lithium clear- ance data for rats undergoing metabolic acidosis. Our results show a proximal sodium rejection followed by an enhanced distal fractional sodium excretion in the absence of any change in creatinine clearance.

In vivo, the nephron mechanism and the site of the renal sodium handling abnormalities have not been identified. The present data show a proximal sodium rejection followed by an enhanced distal fractional sodium excretion in the absence of any change in creatinine clearance. The metabolic acidosis induced by $\mathrm{NH}_{4} \mathrm{Cl}$ resulted in an absolute increase in kidney weight. These data are consistent with in vitro studies of proximal tubule cells (13) which showed that cellular hypertrophy was accompanied by a marked decline in protein degradation but not in cell protein synthesis after the administration of $\mathrm{NH}_{4} \mathrm{Cl}$. Acidification in vitro has failed to produce cellular hypertrophy when not caused by ammonium chloride $(14,15)$, suggesting that the hypertrophy results from the increased production of ammonia rather than from the acidosis per se (16). An increased rate of ammoniagenesis per nephron characterizes the hypertrophy of renal ablation, protein loading, potassium depletion, and ammonium chloride loading. Since internal $\mathrm{pH}$ is perturbed only minimally, increased cellular ammonia availability may act as a stimulus to hypertrophy and may also increase the activity of the $\mathrm{Na}^{+}-\mathrm{H}^{+}$exchanger by acting as a substrate for the trans-

\begin{tabular}{|c|c|c|c|c|c|c|}
\hline Groups & $\begin{array}{l}\text { Body weight } \\
\text { (g) }\end{array}$ & $\begin{array}{l}\text { Renal weight } \\
\text { (g) }\end{array}$ & $\begin{array}{l}\text { Liquid intake } \\
(\mathrm{ml})\end{array}$ & $\begin{array}{l}\mathrm{Na}^{+} \\
(\mathrm{mM})\end{array}$ & $\begin{array}{c}\mathrm{K}^{+} \\
(\mathrm{mM})\end{array}$ & $\begin{array}{c}\mathrm{Li}^{+} \\
(\mu \mathrm{M})\end{array}$ \\
\hline Co & $258 \pm 3.7$ & $1.46 \pm 0.05$ & $34.9 \pm 0.9$ & $143 \pm 0.9$ & $3.7 \pm 0.1$ & $100 \pm 5.0$ \\
\hline PF & $225 \pm 3.6$ & $1.40 \pm 0.05$ & $34.8 \pm 0.5$ & $142 \pm 1.2$ & $3.5 \pm 0.1$ & $113 \pm 6.0$ \\
\hline $\mathrm{NH}_{4}$ & $232 \pm 4.3^{a}$ & $1.73 \pm 0.05^{b}$ & $35.7 \pm 0.7$ & $143 \pm 0.4$ & $4.4 \pm 0.1^{a, b}$ & $109 \pm 8.0$ \\
\hline
\end{tabular}


Figure 1 - Effect of metabolic acidosis on renal creatinine clearance $(\mathrm{CCr})(\mathrm{A})$, fractional sodium $\left(\mathrm{FENa}^{+}\right)$and potassium $\left(\mathrm{FEK}^{+}\right)$ excretion (B), and fractional proximal $\left(\mathrm{PFENa}^{+}\right)$and postproximal $\left(\mathrm{PPFENa}{ }^{+}\right)$tubule sodium excretion (C) in $\mathrm{NH}_{4} \mathrm{Cl}$-fed rats compared to control (Co) and pair-fed (PF) rats. Data are reported as percent of the control or pair-fed values and represent the mean \pm SEM for 10 rats per group. $* \mathrm{P}<0.05$ compared to the control and pair-fed animals (ANOVA).

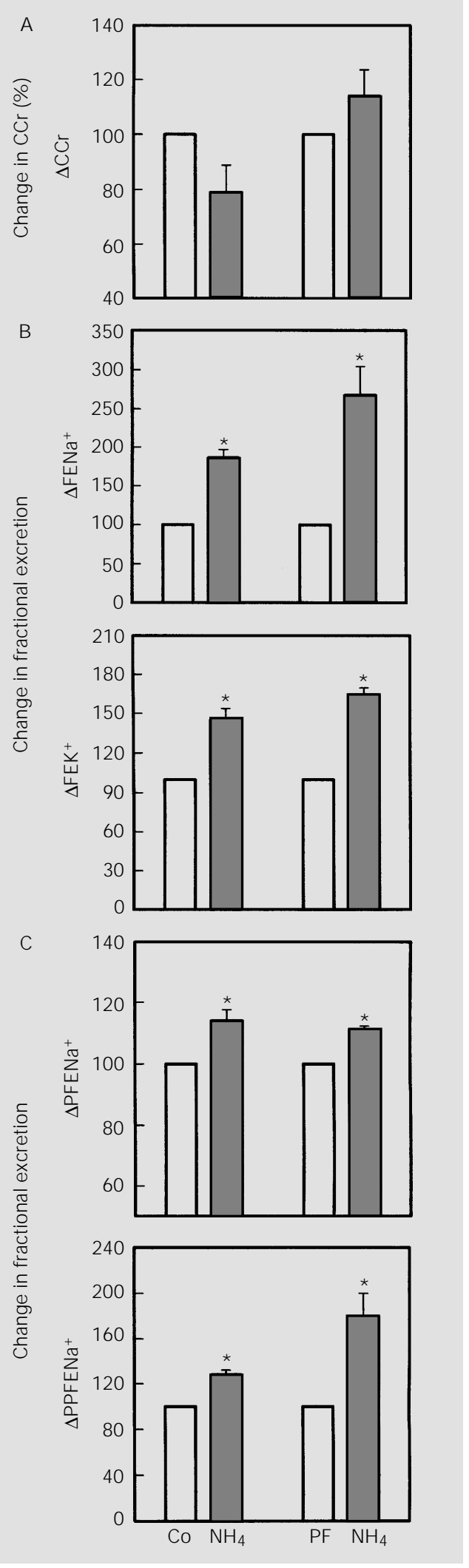

porter on its cytoplasmic side. However, a causal relationship remains to be established. Studies have demonstrated that thyroid hormone stimulates this antiporter without causing hypertrophy, indicating that activation of $\mathrm{Na}^{+}-\mathrm{H}^{+}$exchange activity does not, per se, initiate the growth response (17). Previous studies have shown that alterations in the acid-base balance modify renal gluconeogenesis. Metabolic acidosis stimulates gluconeogenesis in a variety of preparations by increasing the level of phosphoenolpyruvate carboxykinase mRNA and hence enzyme activity $(18,19)$. There is considerable evidence that gluconeogenesis and the reabsorption of $\mathrm{Na}^{+}$are reciprocally related. Thus, American opossum kidney (OK) cells respond to acidosis with increased glutamine metabolism and ammonium formation (20). In these cells, acidosis decreases the activity of the $\mathrm{Na}^{+}-\mathrm{H}^{+}$exchanger, thereby increasing intracellular $\mathrm{H}^{+}(21)$. Studies using isolated proximal tubules have shown that enhanced glutamine metabolism and ammonia production are linked to increased gluconeogenesis (22). On the other hand, maneuvers that inhibit $\mathrm{Na}^{+}-\mathrm{K}^{+}$-ATPase, and hence sodium tubule transport by the kidney, stimulate gluconeogenesis $(23,24)$. Since metabolic acidosis results in a lower filtered load of bicarbonate and consequently in less bicarbonate being reabsorbed, and since decreased $\mathrm{Na}^{+}-\mathrm{H}^{+}$antiporter activity is associated with stimulated gluconeogenesis, the overall effect should be dissipation of the $\mathrm{Na}^{+}$electrochemical gradient leading to a decreased reabsorption of $\mathrm{Na}^{+}$as observed in the present study. The present findings suggest that in energy-requiring processes, renal growth, sodium transport and possibly gluconeogenesis may compete for the available energy in nephron tubules and could explain the striking natriuresis observed in our rats. In contrast to previous studies $(4,25)$, fractional potassium excretion increased during acidosis. Many factors including blood $\mathrm{pH}$, luminal membrane potential, sodium 
delivery to the distal tubule and urinary flow rate have been proposed to have an important influence on the renal excretion of potassium (26). While the present study provides fresh insights on renal $\mathrm{Na}^{+}$excretion in response to chronic metabolic acidosis, it should be borne in mind that the experiments examined whole kidney function in metabolic cages using unanesthetized, unre- strained rats. In conclusion, chronic metabolic acidosis in rats leads to an increased renal weight and ion excretion. This altered renal $\mathrm{Na}^{+}$and $\mathrm{K}^{+}$handling may result from a reciprocal relationship between the level of metabolism of renal tubules and ion transport. Further studies are required to establish the influence of acidosis on renal growth and on renal function.

\section{References}

1. Lennon EJ \& Piering WF (1970). A comparison of the effects of glucose ingestion and $\mathrm{NH}_{4} \mathrm{Cl}$ acidosis on urinary calcium and magnesium excretion in man. J ournal of Clinical Investigation, 49: 14581465.

2. Levine DZ \& Nash L (1973). Effect of chronic $\mathrm{NH}_{4} \mathrm{Cl}$ acidosis on proximal tubular $\mathrm{H}_{2} \mathrm{O}$ and $\mathrm{HCO}_{3}$ reabsorption. American J ournal of Physiology, 225: 380-384.

3. Safirstein R, Glassman VP \& DiScala VA (1973). Effects of $\mathrm{NH}_{4} \mathrm{Cl}$ induced metabolic acidosis on salt and water reabsorption in dog kidney. American J ournal of Physiology, 225: 805-809.

4. Glassman VP, Safirstein R \& DiScala VA (1974). Effects of metabolic acidosis on proximal tubule ion reabsorption in dog kidney. American J ournal of Physiology, 227: 759-765.

5. Stein RM, Abramson RG, Kahn T \& Levitt MF (1967). Effect of hypotonic saline loading in the hydrated dog: evidence for a saline-induced limit on distal tubular sodium transport. J ournal of Clinical Investigation, 46: 1205-1214.

6. Stein J H, Rector J r FC \& Seldin DW (1968). The effect of acute metabolic acidosis on proximal tubular sodium reabsorption in the rat. J ournal of Clinical Investigation, 47: R277 (Abstract).

7. Fine $L$ (1986). The biology of renal hypertrophy. Kidney International, 29: 619-634.

8. Thonsem K \& Shirley DG (1997). The validity of lithium clearance as an index of sodium and water delivery from the proximal tubules. Nephron, 77: 125-138.

9. Quadros MR, Gontijo J AR \& Figueiredo J F (1996). Renal tubular sodium handling determined by lithium clearance in partially hepatectomized rats. Brazilian J ournal of Medical and Biological Research,
29: 1077-1083.

10. Brod J \& Sirota J H (1948). The renal clearance of endogenous creatinine in man. J ournal of Clinical Investigation, 27: 645651.

11. Sartorius OW, Roemmelt J C \& Pitts RF (1949). The renal regulation of acid-base balance in man. IV. The nature of the renal compensations in ammonium chloride acidosis. J ournal of Clinical Investigation, 28: 423-439.

12. Herbert CS, Martinez-Maldonado $M \&$ Suki WN (1972). Relation of bicarbonate to sodium reabsorption in dog kidney. American J ournal of Physiology, 222: 1014-1020.

13. Ling $\mathrm{H}$, Vamvakas $\mathrm{S}$, Gekle $M$, Schaefer $\mathrm{L}$, Teschner M, Shaefer RM \& Heidland A (1996). Role of lysosomal cathepsin activities in cell hypertrophy induced by $\mathrm{NH}_{4} \mathrm{Cl}$ in cultured renal proximal tubule cells. J ournal of the American Society of Nephrology, 7: 73-80.

14. Nash KA, Hostetter $M K \&$ Hostetter $T H$ (1991). Increased ammoniogenesis as a determinant of progressive renal injury. American J ournal of Kidney Diseases, 17: 654-657.

15. J urkovitz CT, England BK \& Kurtz I (1992). Influence of ammonia and $\mathrm{pH}$ on protein and amino acids metabolism in LLC-PK1 cells. Kidney International, 42: 595-601.

16. Kurtz I (1991). Role of ammonia in the induction of renal hypertrophy. American J ournal of Kidney Diseases, 17: 650-653.

17. Fine LG \& Norman J (1989). Cellular events in renal hypertrophy. Annual Review of Physiology, 51: 19-32.

18. Parry DM \& Brosnan JT (1980). Renal phosphoenolpyruvate carboxykinase during perturbation of acid-base homeostasis in rats. Immunochemical studies. Ca- nadian J ournal of Biochemistry, 58: 12981301.

19. Iynedjian PB \& J acob MM (1980). Glucocorticoid-dependent induction of mRNA coding for phosphoenolpyruvate carboxykinase (GTP) in rat kidney. Its inhibition by cycloheximide. European J ournal of Biochemistry, 111: 89-98.

20. Nissin I, States B, Missin I, Lin Z-P \& Yudkoff M (1995). Hormonal regulation of glutamine metabolism by OK cells. Kidney International, 47: 96-105.

21. Miller RT \& Pollack AS (1987). Modification of the internal $\mathrm{pH}$ sensitivity of $\mathrm{Na} / \mathrm{H}$ antiporter by parathyroid hormone in cultured renal cell lines. J ournal of Biological Chemistry, 262: 9115-9120.

22. Nissin I, Missin I \& Yudkoff M (1991). Adaptation of renal tricarboxylic acid cycle metabolism to various acid-base states. Mineral and Electrolyte Metabolism, 17: 21-31.

23. Friedrichs D \& Schoner W (1973). Stimulation of renal gluconeogenesis by inhibition of the sodium pump. Biochimica et Biophysica Acta, 304: 142-160.

24. McGeoch J , Falconer-Smith J, Ledingham J \& Ross BD (1978). Inhibition of active $\mathrm{Na}$, K-ATPase by myeloma protein. Lancet, ii: 17-18.

25. Malnic G, DeMello Aires $M \& \&$ Giebisch $G$ (1971). Potassium transport across renal distal tubules during acid-base disturbances. American J ournal of Physiology, 221: 1192-1208.

26. Wright FS \& Giebisch G (1992). Regulation of potassium excretion. In: Seldin DW $\&$ Giebich G (Editors), The Kidney Physiology and Pathophysiology. Raven Press Ltd., New York, 2209-2247. 